\title{
Polycyclic Aromatic Hydrocarbon Contents of Coral and Surface Sediments off the South Texas Coast of the Gulf of Mexico
}

\author{
Daryl T Sabourin ${ }^{1}$, James E Silliman ${ }^{1} \&$ Kevin B Strychar ${ }^{2}$ \\ ${ }^{1}$ Texas A \& M University-Corpus Christi, Dept. Physical \& Environmental Sciences, Corpus Christi, TX, USA \\ ${ }^{2}$ Annis Water Resources Institute, Grand Valley State University, Muskegon, MI, USA \\ Correspondence: Kevin B. Strychar, Annis Water Resources Institute, Grand Valley State University, 131 Lake \\ Michigan Center, 740 W. Shoreline Dr., Muskegon, MI 49441-1678, USA. Tel: 1-616-331-8796. E-mail: \\ strychak@gvsu.edu
}

Received: September 23, 2012 Accepted: October 11, 2012 Online Published: November 27, 2012

doi:10.5539/ijb.v5n1p1

URL: http://dx.doi.org/10.5539/ijb.v5n1p1

\begin{abstract}
Sediment and coral (Leptogorgia setacea) samples were analyzed for polycyclic aromatic hydrocarbon (PAH) concentrations along the Port Aransas Jetties off the coast of south Texas. Total PAH concentrations ranged from 243-2121 ppm in corals and from 1-328 ppm in sediments. In addition to total PAH concentrations being higher in coral samples, most of the corals also showed higher PAH concentrations in their skeletal cores than their body tissues. Our results suggest that corals are bioaccumulating PAHs. However, more statistical analysis and a larger breadth of samples need to be collected for better resolution. The importance of our observations is that the general trends show bioaccumulation at the beginning of the food chain (i.e., coral) which can have perilous consequences for bivalves, fish, and other organisms that feed in/on and around corals.
\end{abstract}

Keywords: polycyclic aromatic hydrocarbon (PAH), coral, Leptogorgia setacea, sediment, polynuclear aromatic hydrocarbons, bioaccumulation, biomagnification, coastal ecology

\section{Introduction}

Polycyclic Aromatic Hydrocarbons (PAHs) are hydrophobic compounds composed of two or more fused conjugated benzene rings. Since the 1960's, PAHs have generated considerable interest due to their proven carcinogenic implications. PAH's are widely distributed in the air, water, sediments, and living organisms throughout the world (Aizenshtat, 1973; LaFlamme \& Hites, 1978; Wakeham, Schaffner, \& Giger, 1980; Coates, Connel, Bordero, Miller, \& Back, 1986; Kennicutt, Sericano, Wade, Alcazar, \& Brooks, 1987; Lamparczyk, Ochocka, Gryzbowski, Halkiewicz, \& Radecki, 1988; El-Sikaily, Khaled, Nemr, Said, \& Abd-Alla, 2003; Olson, Iverson, Edward, \& Schroeder, 2003). Early studies determined_that some compounds, such as perylene, retene, and permethrin, may be derived through the digenesis of biogenetic precursors, while most other PAHs are introduced into the atmosphere via incomplete combustion of fuels, industrial activities, accidental oil spills, and natural oil seepage (National Academy of Science, 1972; Lee, Prado, Howard, \& Heits, 1977; Wakeham et al., 1980; Tan \& Heit, 1981; Gschwend \& Hites, 1981; Silliman et al., 2000). Concentrations of these compounds have been increasing throughout the last century due to enhanced anthropogenic activities such as industrialization, oil and natural gas exploration, etc. (LaFlamme \& Hites, 1977; Ishiwatari, Ogura, \& Horie, 1980; Gschwend \& Hites, 1981; Tan \& Heit, 1981; Lamparczyk et al., 1988; Burns \& Knap, 1989; Burns \& Yelle-Simmons, 1994; Snedaker, Glynn, Rumbold, \& Corcoran, 1995; Redman et al., 1996; Reddy \& Quinn, 1999; Thomas \& Li, 2000; El-Sikaily et al., 2003; Poulsen, Burns, Lough, Brinkman, \& Delean, 2006).

Once introduced into the atmosphere, the hydrophobic nature of PAH molecules bind to aerosols such as dust particles, settle, and enter the water column eventually building up and contributing to the processes of "sedimentation". During sedimentation, the particulate matter may be ingested directly or through filter-feeding mechanisms by living organisms such as coral, sea cucumbers, and tube worms. The analysis of hydrocarbon data collected from such sediments confirms the long-term persistence of residual PAHs introduced by anthropogenic processes, especially within highly industrialized areas (Aizenshtat, 1973; LaFlamme \& Hites, 1978; Wakeham et al., 1980; Burns \& Yelle-Simmons, 1994). As a consequence, regions centered within densely populated metropolitan areas are of particular concern. 
Prior studies also indicate that PAH's ingested by organisms may be incorporated within living tissue (Gold-Bouchot, Zavala-Coral, Zapata-Perez, \& Ceja-Moreno, 1997; Coates et al., 1986; Burns \& Yelle-Simmons, 1994). Since many PAHs are generally resilient to metabolic processes due to their chemical stability, they characteristically bioaccumulate with mutagenic and carcinogenic consequences. PAHs have been identified in tissues from bivalves, fish, and non-reef building soft and hard bodied corals (Gold-Bouchot et al., 1997; Coates et al., 1985; Burns \& Yelle-Simmons, 1994).

Testing coral for PAHs and other contaminants has been of particular interest to the wider community due to the absorption and storage of compounds in organismal tissues (Gagan et al., 2000; Redman et al., 1996; Burns \& Knap, 1989; Coates et al, 1986) and the potential of bioaccumulation affecting fisheries species and hence, humans. Studies conducted on corals from the Gulf coast of Kuwait and Saudi Arabia have shown that coral skeletal structures composed of calcium carbonate incorporate pollutants during growth, and consequently, also provide historical documentationof local pollution deposition and accumulation (Redman et al., 1996). These authors also noted that concentrations of PAHs within corals could be used to characterize general increases in exposure caused by significant pollution events, e.g. during an oil spill (Redman et al., 1996; Poulsen et al., 2006). This suggests that corals are susceptible to varying PAH concentrations and may bioaccumulate toxins from their environment into their tissues. Poulsen et al. (2006) showed that the overall growth of coral is affected by significant increases in the concentration of PAHs, or by increases in the duration of exposure to pollutants through time. With ever increasing oil spills being observed worldwide, tissue damage to coral may be more pronounced than bioaccumulation.

Along the south Texas coastline, one of the predominant corals present is Leptogorgia sp., family Gorgoniidae, subclass Octocorallia. White and Strychar (2011) recently studied Leptogorgia virgulata and proposed that gorgonian corals endemic to this area could be used as an environmental bioindicator of petroleum contaminants. White and Strychar (2011) found that L. virgulata, when exposed to different concentrations of gasoline, exhibited significant damage and tissue loss. At high gasoline concentrations White and Strychar (2011) observed L. virgulata discarding or "sloughing off" sclerites that make up their chitinous exoskeleton.

Another relatively abundant coral along the south Texas coast is Leptogorgia setacea (Pallas, 1766), which may exist in excess of 700 or more colonies along the Port Aransas jetties (Williamson, Strychar, Withers, \& Sterba-Boatwright, 2011). The central axis of most gorgonian corals is composed of a skeleton made of gorgonin (a complex fibrous protein) and/or calcium carbonate. Their skeleton is covered with a rind and an extremely high concentration of sclerites. Leptogorgia setacea is usually unbranched and connected to a small vacant bivalve shell (De Victor, 2007), or to man-made hardened structures as is the case along the Port Aransas jetty. The single branch is usually between 2 and $4 \mathrm{~mm}$ in diameter and can reach $2 \mathrm{~m}$ in length (Deichmann, 1936). Colonies range in color, but are commonlyobserved as purple or yellow. Atlantic distribution of the species includes the Chesapeake Bay to Florida, the Gulf of Mexico, and from Colombia to Brazil (De Victor, 2007).

Leptogorgia sp., like many other coral, generally consist of a colony of living organisms that derive nutrition from the water column. Its growth is dependent on a multitude of factors. Some of those factors include salinity and temperature (Bayer, 1961; Williamson et al., 2011), orientation within the water column (Wainwright \& Dillion, 1969), spatial distribution between coral colonies (Kinzie, 1970), and water flow across polyps (Jeyasuria \& Lewis, 1987). Since Leptogorgia sp. are very dependent upon nutrient content from the water column, they also tend to be greatly affected by any contaminants introduced into the environment.

Corpus Christi Bay is impacted by deposits of oil and oil by-products due to shipping, refinery activity, and contamination resulting from offshore drilling activity. The Port of Corpus Christi, Texas (Port of CC) is a central hub for thousands of cargo, tanker, and barge vessels, many of which transport crude oil or petroleum products to and from local refineries. In 2010 a recorded total of 5,768 vessels shipped a total of 82,194,297 tons of products, of which 1,468,244 tons were chemicals and 68,900,860 tons were petroleum products (Port of CC, 2011). The Port of CC is the sixth largest port in the United States in total tonnage, and despite the aggressive environmental programs established by port authorities and local municipalities; some level of pollution is unavoidable. In addition to contributions from Port of CC vessel traffic, Corpus Christi is a growing metropolis complete with refineries, power plants, and significant automobile traffic, all of which contribute to PAH deposition. With potential repercussions of contamination affecting many fishery resources of the marine ecosystem, hydrocarbon research is of particular interest to the area.

This study focused on (1) quantifying the presence of PAHs along the shipping channel in Port Aransas, while (2) establishing a correlation between PAH concentrations and the corals living in close proximity. In this study we hypothesized that: 
$\mathrm{H}_{\mathrm{o}}$ : There would be no difference in PAH concentrations in collected coral tissues when compared to surface sediment.

$\mathrm{H}_{\mathrm{A}}$ : There would be a significantly greater PAH concentration in collected coral tissues when compared to surface sediments.

The importance of this study is that it will help establish a baseline for PAH compounds within the region at the furthest extent of the shipping channel from which further studies closer to the port may establish a horizontal contamination gradient along Corpus Christi Bay. Compounds of interest for this study were identified as the 16 PAHs present in a 47543-U-analytical standard, Polynuclear Aromatic Hydrocarbon Mixture, supplied by Sigma Aldrich, which includes: acenaphthene, acenaphthylene, anthracene, benz[a]anthracene, benzo[k]fluoranthene, benzo[ghi]perylene, benzo[a]pyrene, chrysene, fluoranthene, fluorene, indeno[1,2,3-cd]pyrene, 1-methylnaphthalene, 2-methylnaphtalene, naphthalene, phenanthrene, and pyrene.

\section{Materials and Methods}

\subsection{Study Area}

The Aransas Pass $\left(27^{\circ} 50^{\prime} 13^{\prime \prime} \mathrm{N} / 097^{\circ} 02^{\prime} 41^{\prime \prime} \mathrm{W}\right)$ was originally constructed in 1899 but was rebuilt in two follow-up construction phases. The North Jetty was rebuilt in 1906 at a length of $3400 \mathrm{~m}$; the south in 1911, at a length of $2600 \mathrm{~m}$. The channel depth is $\sim 15.85 \mathrm{~m}$. Our study site, the Port Aransas Jetty along the south Texas coast (Figure 1), has a considerably large and abundant number of colonies of Leptogorgia setacea growing at or near the jetty (White \& Strychar, 2011; Williamson et al., 2011). Surface sediments were collected in close proximity to the corals collected in this region.

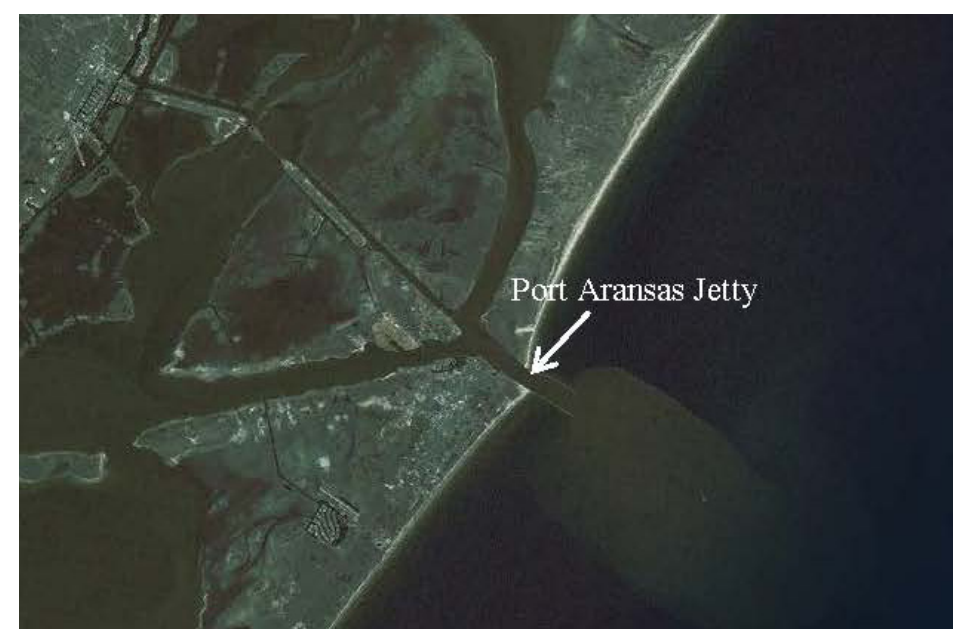

Figure 1. Satellite image of Port Aransas and jetty (satellite imagery from geo.data.gov)

\subsection{Sediment Grab Samples collected along Port Aransas Jetty}

Four samples of coral and four sediment grab samples were collected from locations on both the ocean-side and jetty-side of the Port Aransas Jetty (Figure 2). High energy wave conditions along the jetty required identification of sediment catchment locations among the stone blocks near the jetty and the coral sampled, followed by the collection of sediment. The latitude/longitude and the date of collection for each of the grab samples are listed in Table 1. All grab samples were transported back to the laboratory located at Texas A \& M Corpus Christi following retrieval and were placed in a freezer at $-20^{\circ} \mathrm{C}$ in preparation for freeze-drying. Each sediment grab sample was freeze-dried for $24 \mathrm{~h}$, pulverized to homogenize the sample and set aside for extraction at a later date. 


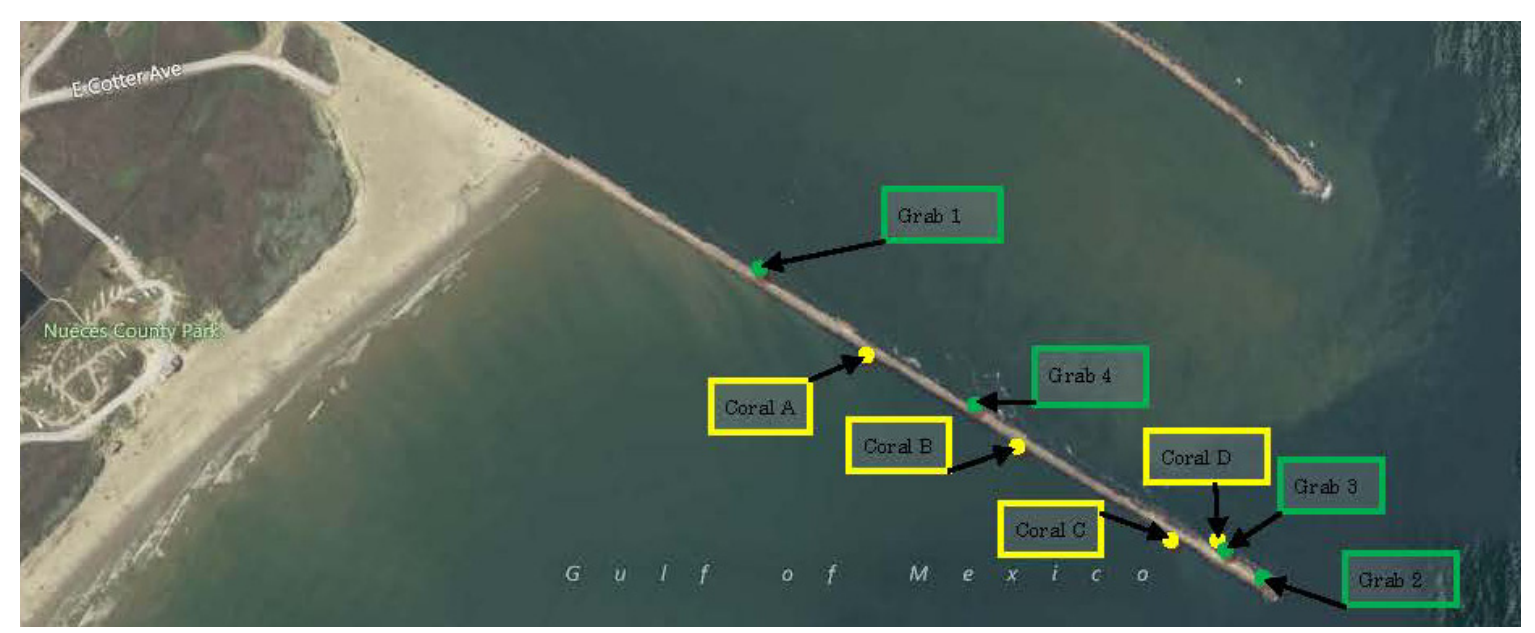

Figure 2. Locations along the Aransas Pass south jetty from which the Leptogorgia setacea and sediment grab samples were retrieved (satellite imagery from geo.data.gov)

Table 1. Locations of sediment grab samples retrieved along the Aransas Pass south jetty

\begin{tabular}{llll}
\hline Sample ID & Date Collected & Latitude & Longitude \\
\hline Grab 1 & 25 March 2010 & N27 49' 59.3” & W097 02' 30.816 \\
Grab 2 & 25 Sept 2011 & N27 49' 46.98 & W097 02' 7.80 \\
Grab 3 & 25 Sept 2011 & N27 49' 46.62 & W097 02' 7.56 \\
Grab 4 & 25 Sept 2011 & N27 49' 53.7 & W097 02' 20.58 \\
\hline
\end{tabular}

\subsection{Coral Samples Collected along Port Aransas Jetty}

Four coral samples (Leptogorgia setacea) were obtained from locations in close proximity to where the sediment grab samples were collected along the Port Aransas southern jetty. Given their affinity to shallower waters, these corals were found sparsely interspersed amongst granite blocks along the jetty (Table 2). During coral collection, each sample was placed in a separate zip-lock bag with sufficient seawater $(\sim 2 \mathrm{~L})$ and placed in a dark cooler for transport back to the laboratory. At the laboratory, the coral were removed from the zip-lock bags, measured for length and width, rinsed with deionized seawater and then separated into two subsamples consisting of (1) coral skeletal samples and (2) coral tissue samples; all coral subsamples were then stored in a freezer at $-20^{\circ} \mathrm{C}$ followed by freeze drying for $24 \mathrm{~h}$.

Table 2. Locations of Leptogorgia setacea samples retrieved along the Aransas Pass south jetty

\begin{tabular}{llll}
\hline Sample ID & Date Collected & Latitude & Longitude \\
\hline Coral A & 16 July 2011 & N27 49' 55.95” & W097 02' 25.69” \\
Coral B & 16 July 2011 & N27 49' 51.893” & W097 02' 18.05” \\
Coral C & 16 July 2011 & N27 49' 48.321” & W097 02' 11.268” \\
Coral D & 16 July 2011 & N27 49' 47.977”, & W097 02' 8.838” \\
\hline
\end{tabular}

All coral collected were yellow in color and presumed healthy since their polyps were all extended during and after collection. In addition, all coral samples had a number of different commensalates associated with them. Of the coral samples collected, the length ranged from $54-80 \mathrm{~cm}$, with an average length of $73 \mathrm{~cm}$.

\subsection{Extraction and Isolation Methods}

The PAH extraction and isolation methods used in this study were the same for all sediment and coral samples. Extraction and isolation techniques used were modified from those found in Silliman, Meyers, P. A. Ostrom, N. 
E. Ostrom and Eadie (2000). For each sediment grab sample, $\sim 10 \mathrm{~g}$ of sediment was measured and placed into a $250 \mathrm{~mL}$ Erlenmeyer flask. Each coral sub-sample was also weighed and placed into a separate $250 \mathrm{~mL}$ Erlenmeyer flask. Coral tissue sub-samples ranged in mass from 0.30-1.4 g and coral skeleton sub-samples ranged from 0.10-0.42 g per sample. All sediment and coral samples were extracted via sonication for $1 \mathrm{~h}$ in 100 $\mathrm{mL}$ of dichloromethane. The solvent extract from each sample was then concentrated down to 1-2 $\mathrm{mL}$ by rotary evaporation followed by nitrogen blow-down. The dichloromethane in each sample was solvent exchanged to petroleum ether by adding and mixing two separate $10 \mathrm{~mL}$ aliquots of petroleum ether and concentrating again to $1 \mathrm{~mL}$ via nitrogen blow-down.

Upon sample concentration, a $1 \times 30 \mathrm{~cm}$ column containing $6 \mathrm{~g}$ of $5 \%$ deactivated silica gel was used to separate extracts into two main fractions, n-alkanes and PAHs, via column chromatography. The concentrated sample was added to the top of the column in which properties of polarity were employed to separate the sample into its two fractions. n-Alkanes (comprising the less polar fraction) were separated by eluting $20 \mathrm{~mL}$ of petroleum ether through the column and PAHs (comprising the more polar fraction) were separated utilizing $16 \mathrm{~mL}$ of a 25:75 solution, dichloromethane to petroleum ether. Each n-alkane and PAH fraction was reduced to $1 \mathrm{~mL}$ of sample via nitrogen blow down in preparation for GC/MS analysis. Finally, all $1 \mathrm{~mL}$ fractions, individually, were treated to remove sulfur by adding a small amount of acid washed copper to each GC/MS vial.

\subsection{Gas Chromatography/Mass Spectrometry (GC/MS)}

Once prepared, the PAH fraction was tested for compounds of interest via GC/MS analysis in order to identify and quantify these compounds. In order to assess the consistency and accuracy of the isolation method, internal standards were utilized for both the n-alkane fraction and PAH fraction. A total of six compounds, three deuterated n-alkanes and three deuterated PAHs, were added prior to sonication of the samples at known concentrations. They were then observed for their presence in each fraction and quantified for loss based upon determined peak intensities and peak areas in the GC/MS data.

An Agilent Technologies 7890 gas chromatograph (GC) paired with an Agilent Technologies 5975C mass spectrometer (MS) detector was used to analyze for PAHs. The GC contained a $25 \mathrm{~m}$ column with a $0.20 \mathrm{~mm}$ diameter that was coated with a $5 \%$ diphenyl and $95 \%$ dimethyl polysiloxane stationary phase. The GC inlet temperature was set a $280^{\circ} \mathrm{C}$. Good separation of compounds was accomplished by the oven temperature program which raised the initial temperature of $35-315^{\circ} \mathrm{C}$ at a rate of $10^{\circ} \mathrm{C} / \mathrm{min}$. The oven was held at $315^{\circ} \mathrm{C}$ at the end of each run for $20 \mathrm{~min}$. The 47543-U PAH standard, obtained from Sigma Aldrich, was diluted to various concentrations and used to establish an internal calibration curve in order to quantify PAHs of interest in sediment and coral samples. Compounds in the PAH standard were identified via the NIST 08 onboard library.

\section{Results and Discussion}

\subsection{Coral Samples collected along Port Aransas Jetty}

PAH concentrations from all coral samples collected are shown in Tables 3 and 4, and Figure 3. Table 3 shows the mean_PAH concentrations of the corals in comparison to the sediment grab samples, broken-down by compound of interest. Total PAHs in coral samples ranged from $\sim 243-2121$ ppm (Table 4) with mean concentrations of $\sim 811 \mathrm{ppm}$ (Table 3 ). 
Table 3. Average polycyclic aromatic hydrocarbon (PAH) concentrations (ppm) of coral (Leptogorgia setacea) and sediment grab samples retrieved along the Aransas Pass south jetty

\begin{tabular}{lcccc}
\hline PAH & $\begin{array}{c}\text { Avg Grab Sample } \\
\text { PAHs }\end{array}$ & $\begin{array}{c}\text { Avg Coral } \\
\text { Body PAHs }\end{array}$ & $\begin{array}{c}\text { Avg Coral } \\
\text { Core PAHs }\end{array}$ & $\begin{array}{c}\text { Avg Coral Body + Core } \\
\text { PAHs }\end{array}$ \\
\hline Naphthalene & 0.03 & 7.01 & 10.34 & 17.35 \\
Naphthalene, 1-methyl- & 2.02 & 13.27 & 11.99 & 25.26 \\
Naphthalene, 2-methyl- & 1.91 & 21.03 & 10.56 & 31.59 \\
Acenaphthylene & 4.01 & 24.22 & 12.12 & 36.35 \\
Acenaphthene & 6.84 & 13.98 & 44.51 & 58.49 \\
Fluorene & 2.42 & 8.96 & 29.82 & 38.78 \\
Phenanthrene & 2.50 & 10.05 & 33.16 & 43.20 \\
Anthracene & 5.66 & 9.06 & 36.56 & 45.62 \\
Fluoranthene & 3.33 & 20.86 & 15.91 & 36.77 \\
Pyrene & 5.35 & 13.91 & 14.67 & 28.58 \\
Benz[a]anthracene & 9.10 & 11.86 & 8.38 & 20.24 \\
Chrysene & 8.66 & 11.77 & 8.38 & 20.15 \\
Benzo[a]pyrene & 4.38 & 13.29 & 54.20 & 67.49 \\
Benzo[k]fluoranthene & 21.17 & 63.49 & 62.98 & 126.47 \\
Indeno[1,2,3-cd]pyrene & 8.61 & 16.19 & 130.80 & 146.99 \\
Benzo[ghi]perylene & 6.67 & 29.89 & 37.48 & 67.38 \\
$\Sigma$ Total PAHs & 92.64 & 288.85 & 521.87 & 810.72 \\
\hline
\end{tabular}

As can be seen in Table 3, the four most abundant PAHs in the coral, in order of concentration, were Indeno[1,2,3-cd]pyrene, Benzo[k]fluoranthene, Benzo[a]pyrene, and Benzo[ghi]perylene. Anderson \& Lee (2006) were able to associate sedimentary PAHs to two main sources, petroleum or pyrogenic, in their study of San Diego Bay. Their biomarker test linked PAHs containing four to six rings to pyrogenic sources. The most abundant PAHs found in the Port Aransas corals contain five to six rings and, as a result, fall into the pyrogenic category.

Table 4. Polycyclic aromatic hydrocarbon (PAH) concentrations (ppm) of coral (Leptogorgia setacea) samples retrieved along the Aransas Pass south jetty

\begin{tabular}{|c|c|c|c|c|c|c|c|c|c|c|c|c|}
\hline Sample ID & $\begin{array}{l}\text { Coral } \\
\text { A } \\
\text { Body }\end{array}$ & $\begin{array}{l}\text { Coral } \\
\text { A Core }\end{array}$ & $\begin{array}{l}\Sigma \\
\text { PAHs } \\
\text { Coral } \\
\text { A }\end{array}$ & $\begin{array}{l}\text { Coral } \\
\text { B } \\
\text { Body }\end{array}$ & $\begin{array}{l}\text { Coral } \\
\text { B Core }\end{array}$ & $\begin{array}{l}\Sigma \\
\text { PAHs } \\
\text { Coral } \\
\text { B }\end{array}$ & $\begin{array}{l}\text { Coral } \\
\text { C } \\
\text { Body }\end{array}$ & $\begin{array}{l}\text { Coral } \\
\text { C Core }\end{array}$ & $\begin{array}{l}\Sigma \\
\text { PAHs } \\
\text { Coral } \\
\text { C }\end{array}$ & $\begin{array}{l}\text { Coral } \\
\text { D } \\
\text { Body }\end{array}$ & $\begin{array}{l}\text { Coral } \\
\text { D } \\
\text { Core }\end{array}$ & $\begin{array}{l}\Sigma \\
\text { PAHs } \\
\text { Coral } \\
\text { D }\end{array}$ \\
\hline Naphthalene & 0.00 & 5.41 & 5.41 & 0.00 & 0.00 & 0.00 & 1.58 & 5.94 & 7.52 & 26.47 & 29.99 & 56.46 \\
\hline Naphthalene, 1-methyl- & 0.00 & 0.00 & 0.00 & 0.00 & 0.00 & 0.00 & 9.84 & 0.00 & 9.84 & 43.26 & 47.95 & 91.21 \\
\hline Naphthalene, 2-methyl- & 1.22 & 0.00 & 1.22 & 0.00 & 0.00 & 0.00 & 12.40 & 0.00 & 12.40 & 70.48 & 42.26 & 112.74 \\
\hline Acenaphthylene & 0.00 & 10.56 & 10.56 & 0.00 & 0.00 & 0.00 & 11.60 & 10.41 & 22.01 & 85.29 & 27.52 & 112.82 \\
\hline Acenaphthene & 0.00 & 15.23 & 15.23 & 0.00 & 0.00 & 0.00 & 20.16 & 11.10 & 31.26 & 35.75 & 151.73 & 187.48 \\
\hline Fluorene & 0.00 & 11.76 & 11.76 & 0.00 & 0.00 & 0.00 & 19.29 & 10.59 & 29.88 & 16.57 & 96.93 & 113.50 \\
\hline Phenanthrene & 0.00 & 25.31 & 25.31 & 2.67 & 0.00 & 2.67 & 26.27 & 9.04 & 35.32 & 11.23 & 98.28 & 109.51 \\
\hline Anthracene & 0.00 & 29.53 & 29.53 & 2.70 & 0.00 & 2.70 & 26.61 & 10.55 & 37.16 & 6.91 & 106.17 & 113.08 \\
\hline Fluoranthene & 0.00 & 23.81 & 23.81 & 2.68 & 0.00 & 2.68 & 37.34 & 8.62 & 45.96 & 43.42 & 31.22 & 74.64 \\
\hline Pyrene & 0.00 & 8.79 & 8.79 & 15.95 & 0.00 & 15.95 & 11.03 & 9.91 & 20.93 & 28.65 & 39.99 & 68.64 \\
\hline Benz[a]anthracene & 1.59 & 0.00 & 1.59 & 3.04 & 0.00 & 3.04 & 7.52 & 0.00 & 7.52 & 35.29 & 33.52 & 68.81 \\
\hline Chrysene & 1.59 & 0.00 & 1.59 & 3.04 & 0.00 & 3.04 & 7.17 & 0.00 & 7.17 & 35.29 & 33.52 & 68.81 \\
\hline Benzo[a]pyrene & 1.68 & 40.67 & 42.35 & 8.45 & 23.62 & 32.08 & 21.96 & 20.92 & 42.89 & 21.08 & 131.57 & 152.65 \\
\hline Benzo[k]fluoranthene & 2.37 & 126.12 & 128.49 & 16.13 & 22.34 & 38.47 & 37.06 & 33.86 & 70.91 & 198.40 & 69.61 & 268.01 \\
\hline Indeno[1,2,3-cd]pyrene & 0.00 & 0.00 & 0.00 & 0.00 & 75.09 & 75.09 & 23.76 & 53.03 & 76.78 & 41.01 & 395.08 & 436.09 \\
\hline Benzo[ghi]perylene & 5.80 & 47.64 & 53.44 & 13.22 & 54.34 & 67.55 & 13.60 & 47.96 & 61.56 & 86.96 & 0.00 & 86.96 \\
\hline$\Sigma$ Total PAHs & 14.26 & 344.83 & 359.09 & 67.90 & 175.39 & 243.30 & 287.18 & 231.92 & 519.10 & 786.05 & $\begin{array}{l}1335.3 \\
5\end{array}$ & $\begin{array}{l}2121.4 \\
0\end{array}$ \\
\hline
\end{tabular}


A.
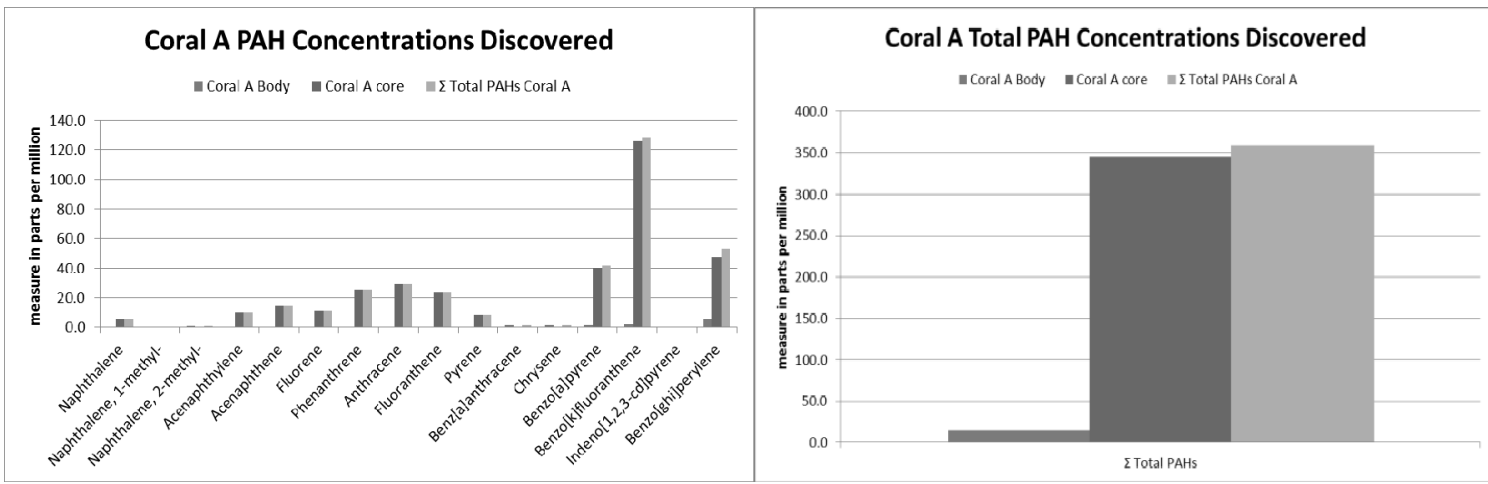

B.
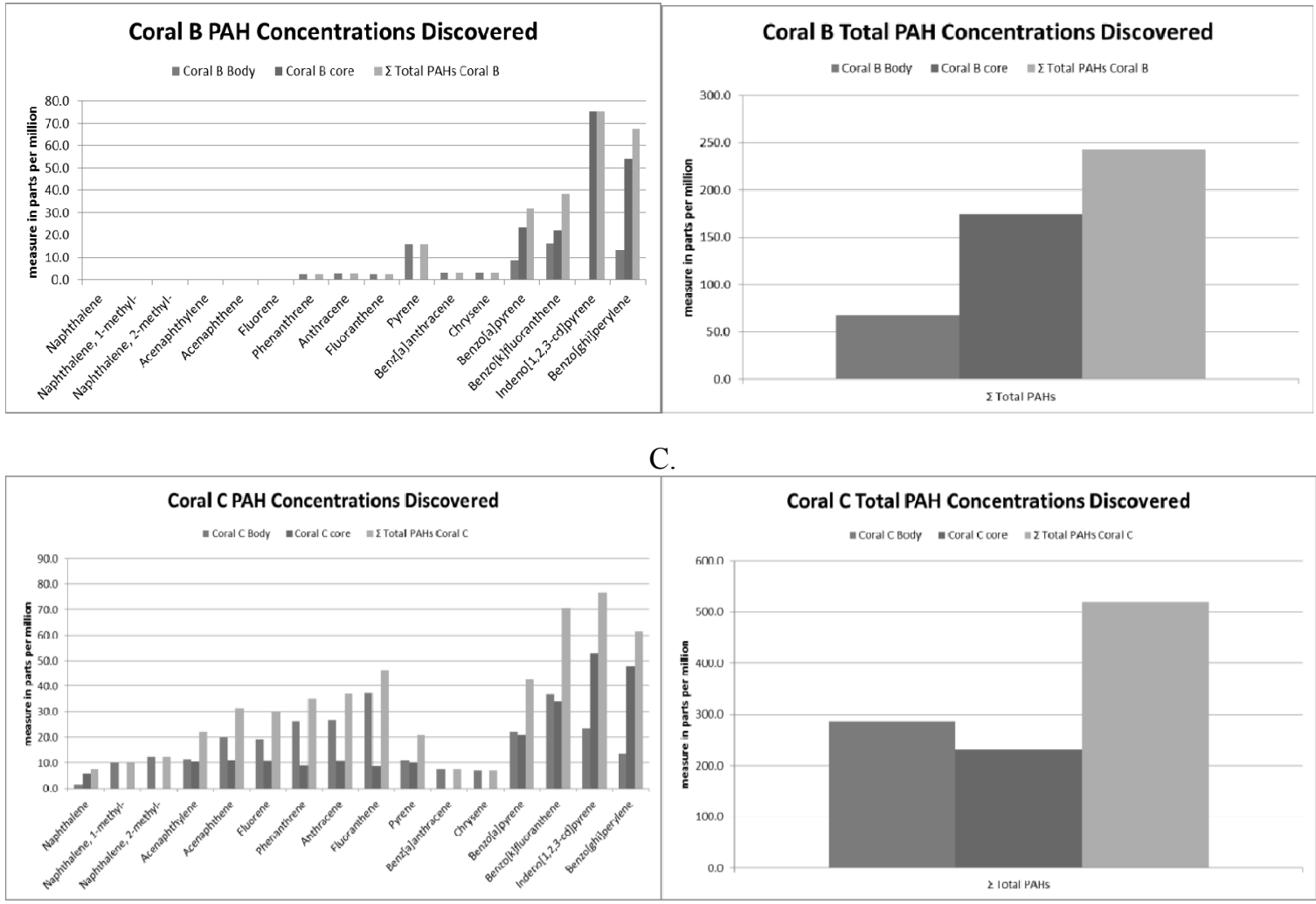

D.
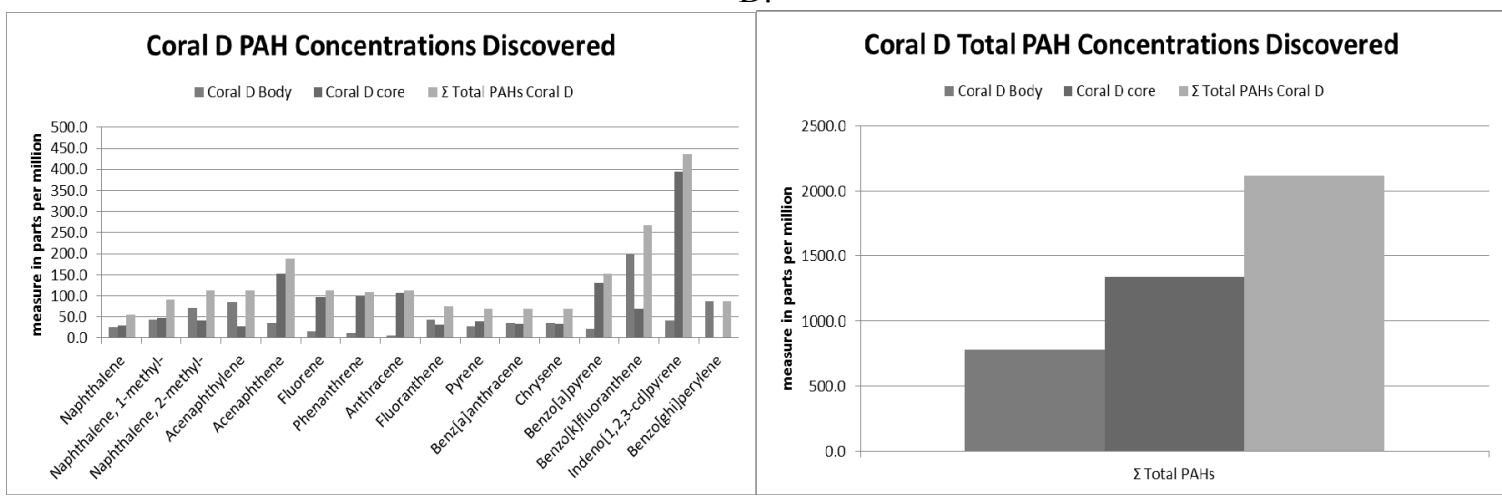

Figure 3. Individual and total polycyclic aromatic hydrocarbon (PAH) concentrations (ppm) of coral, A-D 
In general, lighter (two- and three-ring) PAHs were found near the surface of the sediments, which are typical of petroleum products, versus heavy (four- to six-ring) PAHs found deeper in the sediment, which are characteristically associated with pyrogenic sources. Among these four, Benzo[a]pyrene is cause for concern since humans are particularly vulnerable to skin-susceptible PAH toxicity, increased risk of carcinogenesis, and genotoxicity (DNA damage) all of which exposure may be via water ingestion, air inhalation, or contaminated foods; doses as small as $0.0002 \mathrm{ppm}$ is enough to contaminate breast milk and maternal/placental blood (CASRN, 2012).

The concentration of PAHs within coral tissues was of particular interest in this study because of possible bioaccumulation and/or biomagnification from one trophic level to the next. Based on the data collected, it was determined that a statistical permutation test, which doesn't require normality, was needed to assess the significance between the mean concentration of grab sediments and that of the corals. An $\alpha \leq 0.05$ was selected and the statistical program " $\mathrm{R}$ " was used. To prevent a cumulative effect of introduced error defined by the Bonferroni method (Gotelli \& Ellison, 2006), which would reduce the p-value for each subsequent test within the data set ( $\alpha /$ number of comparisons), only the mean of the total coral-tissue PAH concentrations was compared to the mean of the total sediment grab PAH concentrations. This analysis resulted in the mean of the coral PAH concentrations consistently higher than that of the sediment concentrations; hence the null hypothesis $\left(\mathrm{H}_{\mathrm{o}}\right)$ could not be rejected. The permutation test resulted in $\mathrm{p}=.071$, indicating that the mean difference is not significant. Graphing the data, however, shows general trends which do reflect biomagnification. The data clearly show (e.g. Figure 4) that coral are accumulating contaminants from the water column and contain higher concentrations in their tissue and skeletal structures that the surrounding sediments.

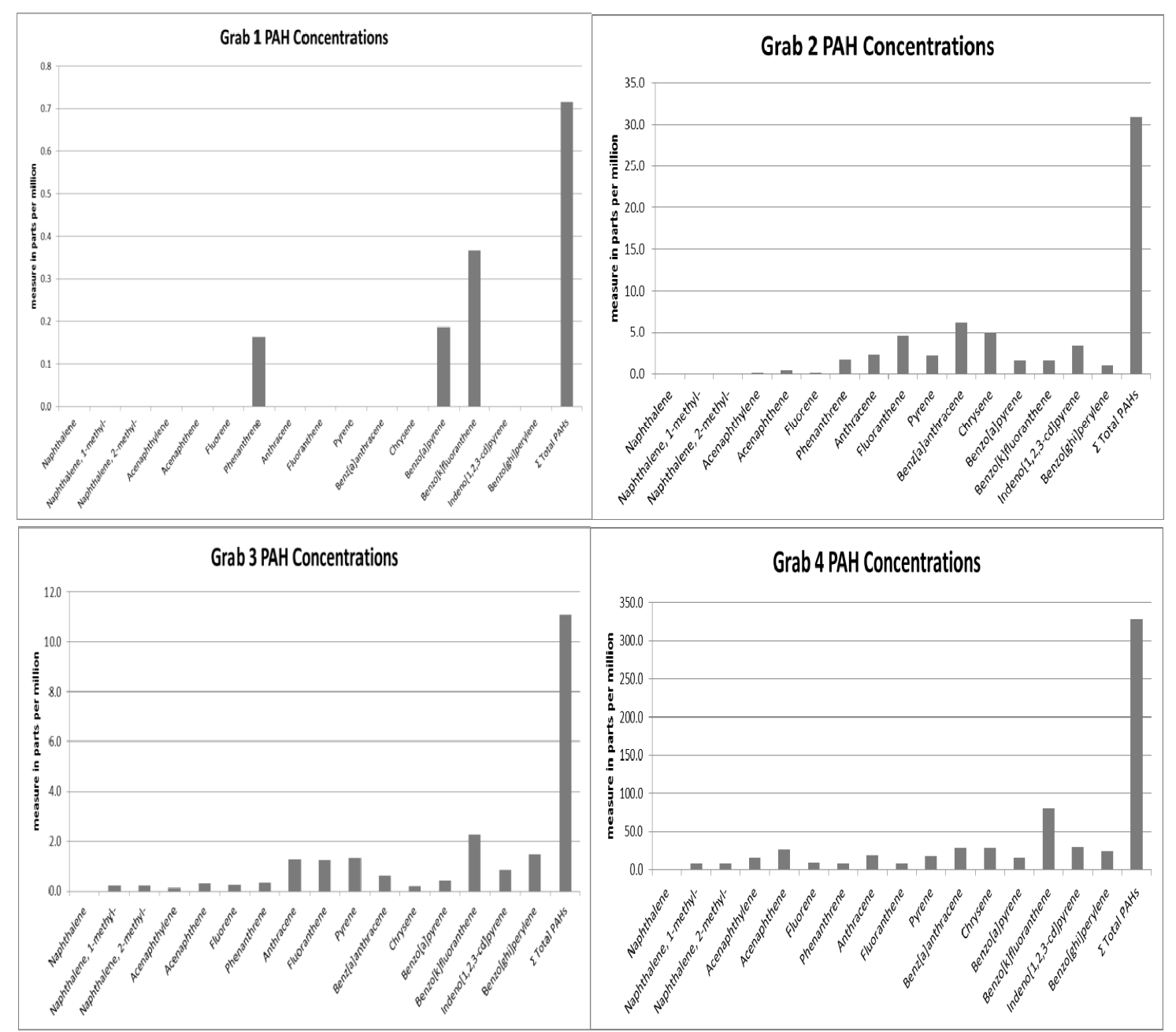

Figure 4. Individual polycyclic aromatic hydrocarbon (PAH) concentrations (ppm) of sediment grab samples retrieved along the Aransas Pass south jetty 
Currently no comparable studies exist that predict trophic level impacts. As a consequence, we recommend a controlled test in which various trophic levels are examined over extended periods of time to clearly determine which fish, for example, are ingesting organic material associated with the coral. In this study, we repeatedly observed people catching fish residing in and near the coral and in all likelihood, feeding on the coral.

We surmise that by increasing " $n$ " by a factor of two to three, the general trends would become significant. This study, however, was constrained by resources that limited the number of samples that could be collected.

Graphing the means of the coral tissues and skeletal cores also showed general trends, where three of the four skeletal cores had higher total PAH concentrations contained within the skeleton. This observation indicates that the coral skeleton has a much greater potential for biodeposition of PAHs than thecoral body tissues.

\subsection{Sediment Grab Samples Collected along Port Aransas Jetty}

Sediment PAH concentrations establish the baseline for total concentrations within_surface sediments along the Port Aransas shipping channel (Table 5; Figure 4). Due to the limited number of samples processed, a higher risk type I statistical error was introduced to the data. Total PAHs in sampled sediments ranged from $\sim 1-328 \mathrm{ppm}$ (Table 5). The four most abundant PAHs in order from highest to lowest concentrations were Benzo[k]fluoranthene, Benz[a]anthracene, Chrysene and Indeno[1,2,3-cd]pyrene. Benzo[k]fluoranthene is of concern as it is a heavy-weight five-ring PAH and considered an EPA priority pollutant because of its relative persistence in tissues over time, its bioaccumulation potential, and its greater carcinogenic and acute toxicity to humans, causing oral and lung tumors (Irwin, VanMouwerik, Stevens, Seese, \& Basham, 1997).

Table 5. Polycyclic aromatic hydrocarbon (PAH) concentrations (ppm) of sediment grab samples retrieved along the Aransas Pass south jetty

\begin{tabular}{lccccc}
\hline PAH & Grab 1 & Grab 2 & Grab 3 & Grab 4 & Average \\
\hline Naphthalene & 0.00 & 0.12 & 0.00 & 0.00 & 0.03 \\
Naphthalene, 1methyl- & 0.00 & 0.00 & 0.21 & 7.85 & 2.02 \\
Naphthalene, 2methyl- & 0.00 & 0.00 & 0.20 & 7.43 & 1.91 \\
Acenaphthylene & 0.00 & 0.16 & 0.14 & 15.75 & 4.01 \\
Acenaphthene & 0.00 & 0.46 & 0.31 & 26.59 & 6.84 \\
Fluorene & 0.00 & 0.22 & 0.23 & 9.21 & 2.42 \\
Phenanthrene & 0.16 & 1.78 & 0.33 & 7.72 & 2.50 \\
Anthracene & 0.00 & 2.33 & 1.29 & 19.02 & 5.66 \\
Fluoranthene & 0.00 & 4.66 & 1.26 & 7.41 & 3.33 \\
Pyrene & 0.00 & 2.26 & 1.35 & 17.78 & 5.35 \\
Benz[a]anthracene & 0.00 & 6.22 & 0.64 & 29.54 & 9.10 \\
Chrysene & 0.00 & 4.89 & 0.19 & 29.54 & 8.66 \\
Benzo[a]pyrene & 0.19 & 1.70 & 0.41 & 15.23 & 4.38 \\
Benzo[k]fluoranthene & 0.37 & 1.67 & 2.27 & 80.36 & 21.17 \\
Ideno[1,2,3-cd]pyrene & 0.00 & 3.43 & 0.84 & 30.17 & 8.61 \\
Benzo[ghi]perylene & 0.00 & 0.97 & 1.46 & 24.23 & 6.67 \\
Total PAHs & 0.72 & 30.87 & 11.13 & 327.83 & 92.64 \\
\hline
\end{tabular}

\section{Conclusion}

Our study has shown that corals (Leptogorgia setacea) along the Port Aransas jetties are affected by exposure to PAHs along the shipping channel. Although the results of this study could not statistically confirm bioaccumulation, the general trends observed in corals analyzed show higher concentrations of PAHs than surface sediments in the same area. The four most abundant PAHs present in the corals, from highest to lowest concentrations, were Indeno[1,2,3-cd]pyrene, Benzo[k]fluoranthene, Benzo[a]pyrene and Benzo[ghi]perylene. Three of the four corals analyzed exhibited higher PAH concentrations in their skeletal cores as compared to 
their body tissues. The four most abundant PAHs present in the surface sediments, from highest to lowest concentrations, were Benzo[k]fluoranthene, Benz[a]anthracene Chrysene and Indeno[1,2,3-cd]pyrene. The significance of the data shows that cancer causing PAHs exist in coral and sediment along the jetty system and have the potential to be bioaccumulated and biomagnified. As a consequence, it is vital that more studies be done to determine what if any risk exist fishing at such locations and whether those risks pose problems to human health. We recommend further studies on sediments along the shipping channel closer to the Port of Corpus Christi and within the Corpus Christi Bay to help identify the full scope of coral exposure to PAHs in these areas. Finally, impact studies on bivalves, fish species, and sea grasses within those locations need to also be conducted to determine if contamination is occurring from one trophic to another and whether we are contaminating our valuable food resources.

\section{Acknowledgments}

We thank Dr. Leslie Adams whose tireless efforts helped in the analysis of TOC, Dr. Paul Zimba and Marci Savage whose expertise were useful in GC/MS analysis, and Dr. Blair Sterba-Boatwright for statistical analysis.

\section{References}

Aizenshtat, Z. (1973). Perylene and its geochemical significance. Geochimica et Cosmochimica Acta, 37, 559-567. http://dx.doi:10.1016/0016-7037(73)90218-4

Anderson, J. W., \& Lee, R. F. (2006). Use of Biomarkers in Oil Spill Risk Assessment in the Marine

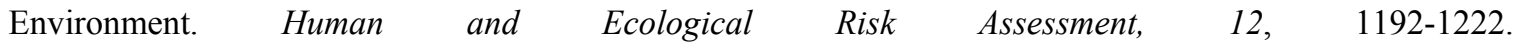
http://dx.doi:10.1080/10807030600976600

Bayer, F. M. (1961). The shallow-waterOctocorallia of the West Indian Region. Martinas Nijhoff, The Netherlands, 373. Retrieved from http://si-pddr.si.edu/dspace/handle/10088/101

Burns, K. A., \& Knap, A. H. (1989). The Bahia las Minas Oil Spill: hydrocarbon uptake by reef building corals. Marine Pollution Bulletin, 20, 198-391. http://dx.doi.org/10.1016/0025-326X(89)90317-2

Burns, K. A., \& Yelle-Simmons, L. (1994). The Galeta oil spill. IV. Relationship between sediment and organism hydrocarbon loads. Estuarine, Coastal and Shelf Science, 38, 397-412. http://dx.doi.org/10.1006/ecss.1994.1027

CASRN. (2012). Polycyclic aromatic hydrocarbons. Retrieved from http:/toxnet.nlm.nih.gov/cgi-bin/sis/search/a?dbs+hsdb:@term+@DOCNO+7092

Coates, M., Connell, D. W., Bordero, J., Miller, G. J., \& Back, R. (1986). Aliphatic hydrocarbons in Great Barrier Reef organisms and environment. Estuarine, Coastal and Shelf Science, 23, 99-113. http://dx.doi.org/10.1016/0272-7714(86)90087-9

Deichman, E. (1936). The Alcyonaria of the western part of the Atlantic Ocean. Harvard University Press., Museum of Comparative Zoology, Harvard, 53, 178-179. http://www.biodiversitylibrary.org/item/25645

De Victor, S. T., \& Morton, S. L. (2007). Guide to the Shallow-Water (0-200 m) Octocorals of the South Atlantic Bight. Retrieved from www.dnr.sc.gov

El-Sikaily, A., Khaled, A., El Nemr, A., Said, T. O., \& Abd-Alla, A. M. A. (2003). Polycyclic Aromatic Hydrocarbons and Aliphatics in the coral reef skeleton of the Egyptian Red Sea coast. Bulletin of Environmental Contamination and Toxicology, 71, 1252-1259. http://dx.doi: 10.1007/s00128-003-8736-x

Gagan, M. K., Ayliffe, L. K., Beck, J., Cole, J., Druffel, E., Dunbar, R., \& Schrag, D. (2000). New views of tropical paleoclimates from corals. Quaternary Science Review, 19, 45-64. http://dx.doi.org/10.1016/S0277-3791(99)00054-2

Gold-Bouchot, G., Zavala-Coral, M., Zapata-Perez, O., \& Ceja-Moreno, V. (1997). Hydrocarbon concentrations in oysters (Crassostrea virginica) and recent sediments from the three coastal Lagoons in Tabasco, Mexico. Bulletin of Environmental Contamination and Toxicology, 59, 430-437. Retrieved from http://biblioteca.cinvestav.mx/indicadores/texto_completo/cinvestav/1997/76483_2.pdf

Gotelli, N. J., \& Ellison, A. M. (2006). A primer of Ecological Statistics. Sinauer Associates, Inc. 10, 345.

Gschwend, P. M., \& Hites, R. A. (1981). Fluxes of polycyclic aromatic hydrocarbons to marine and lacustrine sediments in the northeastern United States. Geochimica et Cosmochimica Acta, 45, 2359-2367. http://dx.doi.org/10.1016/0016-7037(81)90089-2 
Irwin, R. J., Van Mouwerik, M., Stevens, L., Seese, M. D., \& Basham, W. (1997). Environmental contaminants encyclopedia. Natiaonl Parks Service, Water Resources Division, Fort Collins, Colorado. p. 32. Retrieved from http://www.nature.nps.gov/hazardssafety/toxic/

Ishiwatari, R., Ogura, K., \& Horie, S. (1980). Organic Geochemistry of a lacustrine sediment (Lake Haruna, Japan). Chemical Geology, 29, 261-280. http://dx.doi.org/10.1016/0009-2541(80)90024-8

Jeryasuria, P., \& Lewis, J. C. (1987). Mechanical Properties of the Axial Skelton in Gorgonians. Coral Reef, 5, 213-219. http://dx.DOI:10.1007/BF00300967

Kennicutt, M. C. II, Sericano, J. L., Wade, T. L., Alcazar, F., \& Brooks, J. M. (1987). High molecular weight hydrocarbons in Gulf of Mexico continental slope sediments. Deep-Sea Research, 34, 403-424. http://dx.doi.org/10.1016/0198-0149(87)90145-2

Kinzie, R. A. (1970). The Ecology of Gorgonian (Cnidaria, Octocorallia) of Discovery Bay. Jamaica, Yale University, New Haven, 107.

La Flamme, R. E., \& Hites, R. A. (1978). The global distribution of polycyclic aromatic hydrocarbons in recent sediments. Geochimica et Cosmochimica Acta, 42, 289-303. http://dx.doi.org/10.1016/0016-7037(78)90182-5

Lamparczyk, H., Ochocka, R. J., Gryzbowski, J., Halkiewicz, J., \& Radecki, A. (1988). Parameters related to pollution by n-Alkanes and PAH in Baltic water and sediments. Marine Pollution Bulletin, 19, 222-226. http://dx.doi.org/10.1016/0025-326X(88)90235-4

Lee, M. L., Prado, G. P., Howard, J. B., \& Heits, R. A. (1977). Source identification of urban airborne polycyclic aromatic hydrocarbons by gas chromatographic mass spectrometry and high resolution mass spectrometry. Biomedical Mass Spectrum, 40, 182-186. http://dx. doi: 10.4209/aaqr.2008.12.0063

National Academy of Science. (1972). Particulate Polycyclic Organic Matter. National Academy of Sciences. Research Triangle Park, North Carolina.

Okona-Mensah, K. B., Battershill, J., Boobis, A., \& Fielder, R. (2005). An approach to investigating the importance of high potency polycyclic aromatic hydrocarbons (PAHs) in the induction of lung cancer by air pollution. Food and Chemical Toxicology, 43, 1103-1116. http://dx. DOI:10.1016/j.fct.2005.03.001

Olson, M. C., Iverson, J. L., Edward, T. F., \& Schroeder, M. P. (2003). Methods of Analysis by the U. S. Geological Survey National Water Quality Laboratory- Determination of Polycyclic Aromatic Hydrocarbon compounds in sediment by Gas Chromatography/Mass Spectrometry. U. S. Geological Survey, Water Resources Investigation report 03-4318. $\quad$ Retrieved from http://nwql.usgs.gov/Public/pubs/WRIR03-4318/WRIR03-4318.pdf

Pallas, P. S. (1766). Elenchus zoophytorum sistens generum adumbrationes generaliores et specierum cognitarum succinctas descriptiones cum selectis auctorum synomymis (pp. 1-28, 1-451). Hagæ. (F. Varrentrapp). Retrieved from http://gdz.sub.uni-goettingen.de/dms/load/img/?PPN=PPN369526589\&IDDOC=222048

Port of Corpus Christi. (2011). Corpus Christi Regional Profile. p. 2. Retrieved from http://www.ccredc.com/UserFiles/File/2010_Regional_Profile(15).pdf Last accessed 09/10/2012.

Poulsen, A., Burns, K., Lough, J., Brinkman, D., \& Delean, S. (2006). Trace analysis of hydrocarbons in coral cores from Saudi Arabia. Organic Chemistry, 37, 1913-1930. http://dx.doi.org/10.1016/j.orggeochem.2006.07.011

Reddy, C. M., \& Quinn, J. G. (1999). GC-MS analysis of total petroleum hydrocarbons and polycyclic aromatic hydrocarbons in seawater samples after the North Cape Oil Spill. Marine Pollution Bulletin, 38, 126-135. http://dx.doi.org/10.1016/S0025-326X(98)00106-4

Redman, J. W., Tolosa, I., Law, A. T., Bartocci, J., Azemard, S., Hamilton, T., ... Price, A. R. G. (1996). Discrete bands of petroleum hydrocarbons and molecular organic markers identified within massive coral skeletons. Marine Pollution Bulletin, 32, 437-443. http://dx.doi.org/10.1016/0025-326X(96)83974-9

Silliman, J. E., Meyers, P. A., Ostrom, P. H., Ostrom, N. E., \& Eadie, B. J. (2000). Insights into the origin of perylene from isotopic analysis of sediments from Saanich Inlet, British Columbia. Organic Geochemistry, 31, 1133-1142. http://dx.doi.org/10.1016/S0146-6380(00)00120-0

Snedaker, S. C., Glynn, P. W., Rumbold, D. G., \& Corcoran, E. F. (1995). Distribution of n-Alkanes in Marine Samples from Southeast Florida. Marine Pollution Bulletin, 30, 83-89. 
http://dx.doi.org/10.1016/0025-326X(94)00147-2

Tan, Y. L., \& Heit, M. (1981). Biogenic and abiogenic polynuclear aromatic hydrocarbons in sediments from two remote Adirondack lakes. Geochimica et Cosmochimica Acta, 45, 2267-2279. http://dx.doi.org/10.1016/0016-7037(81)90076-4

Thomas, S. D., \& Li, Q. X. (2000). Immunoaffinity Chromatography for Analysis of Polycyclic Aromatic Hydrocarbons in Corals. Environmental Science and Technology, 34, 2649-2654. http://dx.doi:10.1021/es991069d

Wainwright S. A., \& Dillion, J. R. (1969). On the Orientation of Sea Fans (Genus Gorgoria).Biological Bulletin, 136, 130-139. Retrieved from http://www.biolbull.org/content/136/1/130.full.pdf +html

Wakeham, S. G., Schaffner, C., \& Giger, W. (1980). Polycyclic aromatic hydrocarbons in recent lake sedimentsII. Compounds derived from biogenic precursors during early diagenesis. Geochimica et Cosmochimica Acta, 44, 415-429. http://dx.doi.org/10.1016/0016-7037(80)90041-1

White, M. L., \& Strychar, K. B. (2011). Corals as Environmental Bioindicators: Ecological and Morphological Effects of Gasoline on Gorgonian Corals, Leptogorgia virgulata. International Journal of Biology, 3, 63-73. http://www.ccsenet.org/journal/index.php/ijb/article/view/6695

Williamson, E. A., Strychar, K. B., Withers, K., \& Sterba-Boatwright, B. (2011). Effects of salinity and sedimentation on the Gorgonian Coral, Leptogorgia virgulata (Lamarck 1815). Journal of Experimental Marine Biology and Ecology, 409, 331-338. http://dx.doi.org/10.1016/j.jembe.2011.09.014 